Energy Islands 
ENVIRONMENTAL COMMUNICATION, POWER, AND CULTURE

Series Editors

Phaedra C. Pezzullo, University of Colorado Boulder

Salma Monani, Gettysburg College

Editorial Board, Advisory Committee

Robert J. Brulle, Drexel University

Giovanna DiChiro, Swarthmore College

Xinghua Li, Babson College

D. Soyini Madison, Northwestern University

Curtis Marez, University of California San Diego

LeiLani Nishime, University of Washington

Tarla Rai Peterson, University of Texas El Paso

I. Energy Islands: Metaphors of Power, Extractivism, and Justice in Puerto Rico, by Catalina M. de Onís 


\section{Energy Islands}

METAPHORS OF POWER, EXTRACTIVISM, AND JUSTICE IN PUERTO RICO

Catalina M. de Onis

\section{따}

U N I VERSITY OF C A LIFOR N A PRES S 
University of California Press

Oakland, California

(C) 202 I by Catalina M. de Onís

Library of Congress Cataloging-in-Publication Data

Names: Onís, Catalina M. de, 1986- author.

Title: Energy Islands : metaphors of power, extractivism, and justice in Puerto Rico / Catalina M. de Onís.

Other titles: Environmental communication, power, and culture ; I.

Identifiers: LCCN 2020051958 (print) | LCCN 2020051959 (ebook) | ISBN 97805203806 I5 (cloth) | ISBN 9780520380622 (paperback) | ISBN 9780520380639 (epub)

Subjects: LCSH: Power resources-Puerto Rico. | Energy policy-Puerto Rico.

Classification: LCC HD9502.P92 D4 2021 (print) | LCC HD9502.P92 (ebook)| DDC $333.79097295-\mathrm{dc} 23$

LC record available at https://lccn.loc.gov/2020051958

LC ebook record available at https://lccn.loc.gov/2020051959

Manufactured in the United States of America

$\begin{array}{lllllllll}29 & 28 & 27 & 26 & 25 & 24 & 23 & 22 & 21\end{array}$

$\begin{array}{llllllllll}\text { IO } & 9 & 8 & 7 & 6 & 5 & 4 & 3 & 2 & \text { I }\end{array}$ 
Para Tata, Hilda y Nitza, con mucho afecto

And to all those imagining and implementing more just, equitable, and sustainable relations 
